\title{
Exstrophy variant in a female child
}

\author{
Eliana Costantino, George S Ganesan
}

Children's Urology Associates, Las Vegas, Nevada, USA

\section{Correspondence to Eliana Costantino,} elianacb@gmail.com

Accepted 16 May 2017

\section{DESCRIPTION}

Bladder exstrophy-epispadias complex is a spectrum of rare congenital malformations involving the urinary, genital and musculoskeletal systems. The condition can be subdivided into classic/ typical forms, comprising epispadias, classical bladder and cloacal exstrophy, and variant/atypical forms, including duplicated, covered and pseudoexstrophy. Diagnosis can be made clinically. Incidence varies. However, the occurrence is higher in males. Genetic and environmental components likely contribute to the aetiopathogenesis, which remains unknown. ${ }^{12}$ There is a hypothesis that cloacal exstrophy variant could result from an ischiopagus conjoined twinning with blighting of one twin.

We present a 9-year-old girl with urinary incontinence. She was initially referred at $2-1 / 2$ years for ambiguous genitalia but did not continue follow-up. The mother denied receiving prenatal care or completing postnatal studies. On examination, she has a bifid clitoris, symphysis pubis widely separated and low-placed umbilicus with midline muscle defect where the bladder seemed to herniate (figure 1). Genetic studies reported normal female karyotype and Fluorescence in situ hybridization (FISH) result, and negative FISH result for sex-determining region Y (SRY). Testosterone level and renal ultrasound were unremarkable. Kidney, ureter, and bladder X-ray (KUB) demonstrated widening of the pubic symphysis

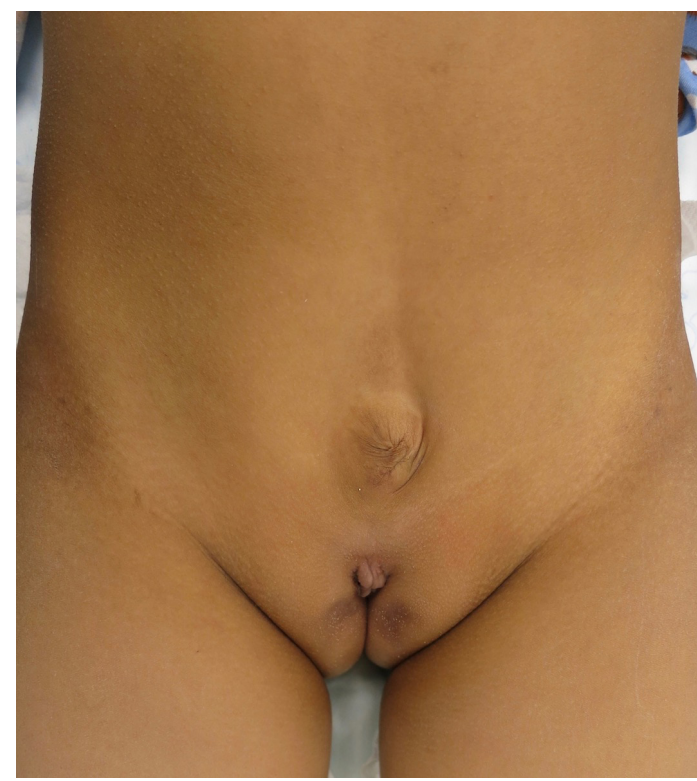

Figure 1 Bifid clitoris and umbilicus located below the horizontal line of the iliac crest.

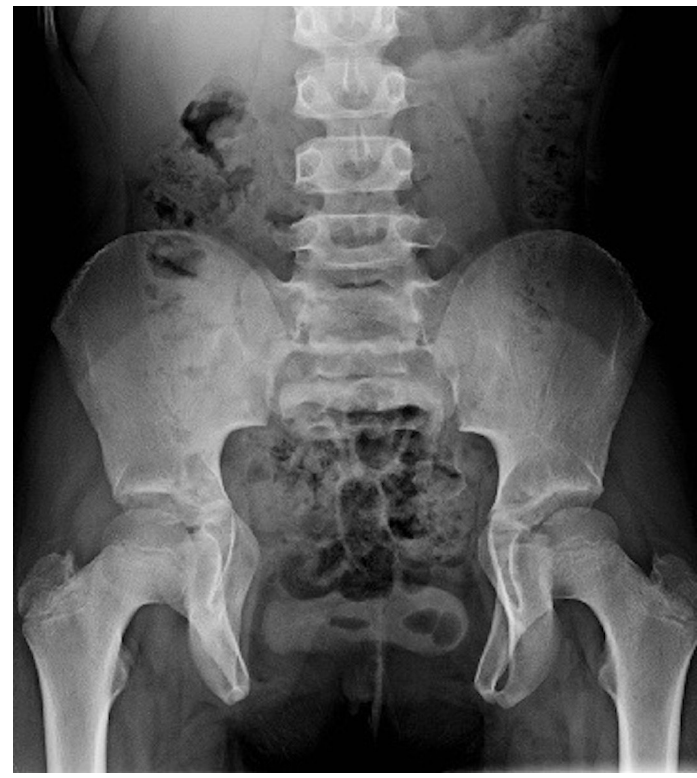

Figure 2 Widening of the pubic symphysis.

(figure 2). Voiding cystourethrogram (VCUG) ruled out ureterocele and vesicoureteral reflux and showed foreshortened urethra. Dynamic urography and magnetic resonance imaging (MRI) were pending, anticipating transfer of care to another centre for surgical management.

Treatment focuses on securing abdominal wall closure, achieving urinary continence with renal function preservation and obtaining adequate cosmetic and functional reconstruction. Pelvic osteotomies are often used to approximate the pubic diastasis, with postoperative immobilisation to facilitate a tension-free surgical repair. ${ }^{12}$ However, management is challenging, and spontaneous voiding cannot be guaranteed.

Learning points

- Bladder exstrophy-epispadias complex is a spectrum of challenging congenital malformations, ranging from classic or typical forms to variant or atypical forms.

- Widening of the pubic symphysis is a feature consistent with the spectrum of closed bladder exstrophy-epispadias complex.

- Comprehensive prenatal care, including detailed ultrasound evaluation during pregnancy, could be key in determining the exact aetiology of exstrophy cases and its variants. 
Contributors All persons who meet authorship criteria are listed as authors, and all authors certify that they have participated sufficiently in the work to take responsibility for the content as guarantors. All authors participated equally in the concept and design. EC contributed to the literature review and manuscript preparation. GSG helped with implementation and revision. All authors contributed to the reporting and approved the final manuscript. The authors would like to thank Dr. Michael E. Mitchell, who provided great insight and expertise to this case.

Competing interests None declared.

Patient consent Obtained.

Provenance and peer review Not commissioned; externally peer reviewed.
(C) BMJ Publishing Group Ltd (unless otherwise stated in the text of the article) 2017. All rights reserved. No commercial use is permitted unless otherwise expressly granted.

\section{REFERENCES}

1 Baradaran N, Gearhart JP. Bladder Exstrophy-Epispadias-Cloacal exstrophy complex: a Contemporary Overview. Neoreviews 2010;11:e705-e713.

2 Ebert AK, Reutter H, Ludwig M, et al. The exstrophy-epispadias complex. Orphanet I Rare Dis 2009:4:23.

3 Casale P, Grady RW, Waldhausen JH, et al. Cloacal exstrophy variants. can blighted conjoined twinning play a role? I Urol 2004;172:1103-7.

Copyright 2017 BMJ Publishing Group. All rights reserved. For permission to reuse any of this content visit

http://group.bmj.com/group/rights-licensing/permissions.

BMJ Case Report Fellows may re-use this article for personal use and teaching without any further permission.

Become a Fellow of BMJ Case Reports today and you can:

- Submit as many cases as you like

- Enjoy fast sympathetic peer review and rapid publication of accepted articles

- Access all the published articles

Re-use any of the published material for personal use and teaching without further permission

For information on Institutional Fellowships contact consortiasales@bmjgroup.com

Visit casereports.bmj.com for more articles like this and to become a Fellow 